\title{
Pengaruh Sistem Informasi Manajemen Kepegawaian Terhadap Pengambilan Keputusan Pimpinan dalam Pengembangan Karier Pegawai
}

\author{
Nur Azizah', Dematria Pringgabayu ${ }^{2}$, Kunto Ajibroto ${ }^{3}$ \\ ${ }^{1}$ Program Studi Manajemen Perhotelan \\ Politeknik Pajajaran ICB Bandung \\ ${ }^{2,3}$ Program Studi Keuangan dan Perbankan \\ Politeknik Pajajaran ICB Bandung \\ E-mail: nurazizah3688@gmail.com ${ }^{1}$,dematria.pringgabayu@poljan.ac.id ${ }^{2}$
}

\begin{abstract}
ABSTRAK
Masalah yang menjadi kajian dari penelitian ini adalah mengenai Pengambilan Keputusan Pimpinan dalam Pengembangan Karir Karyawan. Salah satu faktor tersebut adalah sistem informasi manajemen yaitu sistem informasi manajemen kepegawaian. Berdasarkan hal tersebut, pokok masalah yang diungkap dalam penelitian ini adalah adakah pengaruh sistem informasi manajemen kepegawaian terhadap pengambilan keputusan pimpinan dalam pengembangan karier pegawai. Metode penelitian yang digunakan adalah metode deskriptif, Teknik analisis data yang digunakan adalah uji regresi sederhana. Berdasarkan perhitungan diperoleh hasil hipotesis alternatif yang menyatakan Terdapat Pengaruh Sistem Informasi Manajemen Kepegawaian (X) Terhadap Pengambilan Keputusan Pimpinan Dalam Pengembangan Karier Pegawai (Y) di Di Sekretariat Daerah Provinsi Jawa Barat.
\end{abstract}

Kata kunci: Sistem Informasi Manajemen, Pengambilan Keputusan Pimpinan, Pengembangan Karir Karyawan

\section{ABSTRACT}

The problem that becomes the study of this research is the Leadership Decision Making in Employee Career Development. One such factor is the management information system, which is the staffing management information system. Based on this, the main problem revealed in this study is whether there is an influence of staffing management information systems on leadership decision making in employee career development. The research method used is descriptive method, data analysis technique used is a simple regression test. Based on the calculation, an alternative hypothesis is obtained that states "There is an Influence on the Personnel Management Information System $(X)$ on Leadership Decision Making in Employee Career Development $(Y)$ in the Regional Secretariat of West Java Province".

Keywords: Management Information Systems, Leadership Decision Making, Employee Career Development

\section{PENDAHULUAN}

Sumber daya manusia (SDM) merupakan sumber daya terpenting yang dimiliki oleh suatu organisasi, dengan kata lain bahwa sumber daya manusialah yang dapat 
membuat sumber-sumber lain dari sebuah organisasi berfungsi. Namun SDM yang dimiliki oleh setiap organisasi tidak dengan sendirinya mampu bekerja efektif tanpa adanya program pengembangan SDM yang komprehensif dan sistematis. Pengembangan SDM mutlak diperlukan apabila organisasi ingin berkembang, maju dan tetap eksis.

Sebuah sistem informasi mampu mengolah data-data menjadi sebuah informasi yang sangat berguna sekali bagi proses pengambilan keputusan yang dilakukan pemimpin. Informasi sangat penting dalam pengambilan keputusan karena merupakan kebutuhan yang paling awal bagi pengambil keputusan yang turut menentukan kualitas pengambilan keputusan dan keputusan yang diambil. Hal tersebut sesuai dengan pendapat Sylagi dan Wallace (Hayati, 2004) bahwa :

Informasi merupakan kebutuhan paling awal bagi pengambil keputusan yang meliputi beberapa jenis informasi berkenaan dengan perhitungan atas (1) tindakan, (2) hasil, (3) kemungkinan-kemungkinan dan pertimbangan atas (i) tujuan, (ii) prefensi dan (iii) pemasaran.

Pentingnya keberadaan data dan informasi yang bermutu sekarang ini diakui dan dirasakan benar oleh oang-orang yang memiliki tugas dan fungsi sebagai pengambil keputusan dalam sebuah organisasi, apalagi dengan pesatnya arus informasi dan teknologi yang berkembang, data dan informasi yang disajikanpun diharapkan dapat memberikan kemudahan bagi pimpinan dalam menentukan arah dan tujuan organisasi secara lebih baik.

Menyadari akan pentingnya data dan informasi khususnya mengenai kepegawaian dalam rangka pengembangan karier pegawai, maka pengelola sistem informasi dituntut untuk memberikan perhatian yang serius dalam pengelolaannya. (Yapary, 2013). Keseluruhan proses data dan informasi tersebut berada dalam satu sistem yaitu Sistem Informasi Manajemen (SIM) dan sistem informasi yang berkenaan dengan orang yakni para pegawai atau anggota organisasi yang bersangkutan ada pada Sistem Informasi Manajemen Kepegawaian (SIMPEG).

Sementara itu, upaya untuk mendukung pemantapan administrasi Kepegawaian di Biro Kepegawaian Sekretariat Daerah Provinsi Jawa Barat telah dimulai dengan pembangunan SIMPEG pada tahun 1994 di 21 Provinsi, sedangkan pengembangan 
selanjutnya terus dilaksanakan hingga saat ini melalui berbagai kegiatan yang meliputi :

1. Pemutakhiran database pegawai serangkaian kegiatan peremajaan database kepegawaian seperti mutasi pengangkatan Pegawai Negeri Sipil (PNS), Mutasi Pangkat, Mutasi Kenaikan Gaji Berkala, Mutasi Pendidikan dan mutasi-mutasi lainnya berdasarkan organisasi dan individu;

2. Perubahan kodefikasi pada tabel induk yang meliputi tabel organisasi, tabel unit kerja, tabel wilayah, tabel pendidikan umum, dan tabel-tabel lainnya yang fleksibel sesuai dengan dinamika organisasi;

3. Perubahan jenis data, elemen data dan struktur database pegawai sebagai bagian perubahan pemutakhiran database dan perubahan kodefikasi pada tabel induk.

Seorang pemimpin membutuhkan informasi yang lengkap, benar dan up-to-date yang berkenaan dengan para pegawai atau anggota organisasi yang bersangkutan. Dengan sistem yang baik pimpinan dapat memperoleh data mengenai jenis dan jenjang pendidikan, usia dan jenis kelamin, pengalaman kerja, pengalaman jabatan, prestasi jabatan, loyalitas dan lain sebagainya yang menunjang bagi pengambilan keputusan pimpinan dalam pengembangan karier pegawai.

Dengan sistem informasi yang baik pimpinan dapat memperoleh data misalnya mengenai penataran, tingkat pendidikan pegawai-pegawainya, rasio antara yang berpendidikan tinggi, menengah dan rendah, pengalaman mereka masing-masing pada waktu lampau, minat mereka. Macam pekerjaan yang sesuai bagi mereka masing-masing dan lain sebagainya. Dengan informasi yang sistematis, pimpinan akan lebih banyak tepat dalam mengambil keputusan di bidang kepegawaian, misalnya pemberian pekerjaan yang tepat, kapan promosi perlu dilaksanakan, dan lain sebagainya. (Ibnu, 2000)

Dapat dilihat bahwa pimpinan di lingkungan Biro Kepegawaian Sekretariat Daerah Provinsi Jawa Barat belum dapat melaksanakan fungsi sistem informasi manajemen kepegawaian dalam menunjang pemimpin untuk dapat mengambil keputusan bagi pengembangan karier pegawainya. Sehingga dapat dihasilkan pegawai yang benarbenar memiliki kinerja yang baik sesuai dengan fungsi dan jabatannya masingmasing yang ditunjang berdasarkan informasi yang diperoleh pimpinan dari sistem 
informasi manajemen kepegawaian.

\section{LANDASAN TEORI}

\section{Sistem Informasi Manajemen Kepegawaian}

Sistem Informasi Manajemen disampaikan oleh Gie (Lasmaya, 2016), yaitu Keseluruhan jalinan hubungan antara satuan-satuan dan jaringan lalu lintas, macam-macam keterangan dalam sesuatu organisasi serta segenap proses pengumpulan, pengolahan, penyimpanan, pengambilan kembali dan penyebaran keterangan itu dengan berbagai peralatan sehingga memungkinkan para anggota melaksanakan tugas dengan sebaik-baiknya maupun pimpinan membuat keputusan atau menjalankan tugas kepemimpinannya yang lain secara tepat.

Human Resources Information Sistem (HRIS) ini dalam Bahasa Indonesia dikenal dengan nama Sistem Informasi Manajemen Kepegawaian (SIMPEG), yaitu berkenaan dengan merancang format-format data kepegawaian dan mengatur sistem pengumpulan, pengolahan, penyimpanan dan pelaporan informasi kepegawaian yang terdiri dari data pegawai, data jabatan, data pendidikan, data penghargaan, data pendidikan dan pelatihan, data keluarga, data kehadiran dan lainlain, sehingga dapat dikelola informasi tentang perencanaan kebutuhan pegawai, penilaian kinerja, pembinaan dan pengembangan karirnya, kesejahteraan, serta pemberhentian atau kepensiunannya. (Lipursari, 2013). Adapun nama lain dari Sistem Informasi Sumber Daya Manusia (SISDM) adalah sistem informasi karyawan, sistem informasi personalia dan banyak nama lainnya.

Sedangkan yang dimaksud dengan Sistem Informasi Manajemen Kepegawaian (SIMPEG) berdasarkan Keputusan Menteri Dalam Negeri No.17 tahun 2000, yaitu :Merupakan suatu totalitas yang terpadu terdiri atas perangkat pengolah meliputi pengumpul, prosedur, tenaga pengolah dan perangkat lunak, perangkat penyimpanan meliputi pusat data dan bank data serta perangkat komunikasi yang saling berkaitan, saling ketergantungan dan saling menentukan dalam rangka penyediaan informasi di bidang kepegawaian. Sistem Informasi Manajemen Kepegawaian menurut adalah "Prosedur sistematik untuk pengumpulan, menyimpan, mempertahankan, menarik, memvalidasi data yang dibutuhkan oleh sebuah perusahaan untuk meningkatkan keputusan SDM”. (Erpurini, 2019) 


\section{Pengambilan Keputusan Pimpinan}

Seorang pemimpin selalu dituntut untuk menunjukkan kinerja terbaiknya dalam mengambil sebuah keputusan. Mereka selalu dituntut tidak saja untuk membuat keputusan berdasarkan masalah yang sedang dihadapi, tetapi mereka juga diharapkan mampu untuk membuat keputusan untuk menghindari terjadinya peristiwa yang tidak diinginkan.(Hasibuan, 2014). Namun dalam kenyataannya terkadang seorang pengambil keputusan selalu dihadapkan pada sejumlah hambatan dan resiko yang harus dihadapi. Hambatan-hambatan tersebut dapat dihindari bila setiap pemimpin menyadari benar akan faktor-faktor penentu yang mempengaruhi dalam mengambil sebuah keputusan.

Beberapa faktor yang dapat menentukan atau mempengaruhi dalam pengambilan keputusan, antara lain : (Ibnu, 2000)

a. Keadaan intern organisasi

Keadaan intern organisasi sangat berpengaruh terhadap pengambilan keputusan. Keadaan tersebut meliputi : dana yang tersedia, kemampuan karyawan, kelengkapan dari peralatan, struktur organisasinya, ketersediaan informasi yang dibutuhkan oleh pimpinan, dan lain sebagainya. Jika seorang pemimpin akan mengambil keputusan yang memerlukan biaya, tetapi dana yang tersedia tidak mendukungnya, maka keputusan yang diambil tidak optimal. Begitu pula dengan keputusan yang berkaitan dengan karyawan, dengan terpaksa pimpinan mengambil keputusan disesuaikan dengan kualitas dan kuantitas karyawan yang ada, dan seterusnya.

b. Tersedianya informasi yang dibutuhkan

Keputusan yang diambil untuk menyelesaikan masalah dalam organisasi. Masalah yang dihadapi organisasi itu pun beranekaragam tergantung dari situasi dan kondisinya pada saat itu, dengan demikian usaha pemecahannya pun harus berbeda. Untuk dapat memecahkan masalah tersebut, seorang pembuat keputusan harus mengetahui apa penyebab dari masalah itu, dan apa akibat yang akan dihadapi jika masalah itu tidak segera dipecahkan. Oleh karenanya, diperlukan data-data baik yang berhubungan langsung maupun tidak untuk kemudian data tersebut diolah dan menjadi sebuah informasi. 
Atas dasar informasi yang diperoleh itulah pengambilan keputusan dapat dilakukan dengan baik.

c. Keadaan ekstern organisasi

Dalam sebuah sistem organisasi terbuka, kegiatan organisasi tidak dapat terlepas dari pengaruh lingkungan luar. Antara organisasi dan lingkungan ekstern akan saling mempengaruhi. Oleh karena itu pengambilan keputusan harus juga memperhitungkan faktor yang mempengaruhi yang datang dari luar organisasi, misalnya keadaan ekonomi, sosial, politik, hukum, budaya dan lain sebagainya.

d. Kepribadian dan kecakapan pengambil keputusan

\section{Pengembangan Karier Pegawai}

Pengembangan karier merupakan suatu proses yang berkelanjutan memberikan kesempatan kepada pegawai untuk mengembangkan minat, kebutuhan dan pilihan karier dalam organisasi. Melalui pengembangan karier pegawai dibantu untuk menentukan tujuan realistis dan kemampuan-kemampuan yang diperlukan untuk jabatan yang disandangnya.

Unsur-unsur yang dijadikan substansi dalam pengembangan karier mencangkup penilaian individu, penilaian organisasi, informasi jabatan karier dalam organisasi dan penyuluhan karier.

Dubrin (Mangkunegara, 2013) mengemukakan tujuan dari pengembangan karier, yaitu :

a. Membantu dalam pencapaian tujuan individu dan perusahaan, maksudnya pengembangan karier membantu pencapaian tujuan perusahaan dan tujuan individu. Seorang pegawai yang sukses dengan prestasi kerja sangat baik kemudian menduduki posisi jabatan yang lebih tinggi, hal ini berarti tujuan perusahaan dan tujuan individu tercapai.

b. Menunjukkan hubungan kesejahteraan pegawai, maksudnya perusahaan merencanakan karier pegawai dengan meningkatkan kesejahteraannya agar pegawai lebih tinggi loyalitasnya.

c. Membantu pegawai menyadari kemampuan potensi mereka, maksudnya pengembangan karier membantu menyadarkan pegawai akan kemampuannya 
untuk menduduki suatu jabatan tertentu sesuai dengan potensi dan keahliannya.

d. Memperkuat hubungan antara pegawai dan perusahaan, maksudnya pengembangan karier akan memperkuat hubungan dan sikap pegawai terhadap perusahaannya.

e. Membuktikan tanggungjawab sosial, maksudnya pengembangan karier suatu cara menciptakan iklim kerja yang positif dan pegawai-pegawai menjadi lebih bermental sehat.

f. Membantu memperkuat pelaksanaan program-program perusahaan, maksudnya pengembangan karier membantu program-program perusahaan lainnya agar tujuan tecapai.

g. Mengurangi turn-over dan biaya kepegawaian, maksudnya pengembangan karier dapat menjadikan turn-over rendah dan begitu pula biaya kepegawaian menjadi lebih efektif.

h. Menggiatkan analisis dari keseluruhan pegawai, maksudnya perencanaan karier dimaksudkan mengintegrasikan perencanaan kerja dan kepegawaian.

Menggiatkan suatu pemikiran (pandangan) jarak waktu yang panjang, maksudnya pengembangan karier berhubungan dengan jarak waktu yang panjang. Hal ini karena penempatan suatu posisi jabatan memerlukan persyaratan dan kualifikasi yang sesuai dengan porsinya

\section{METODE PENELITIAN}

Dalam penelitian ini metode yang digunakan adalah metode deskriptif, yaitu untuk melihat keterikatan antara dua variabel atau lebih melalui analisa data yang didapat. Metode deskriptif lebih menekankan pada suatu studi untuk memperoleh informasi mengenai gejala yang muncul pada saat penelitian berlangsung. (Arikunto, 2010). Seluruh subjek yang ada dalam wilayah penelitian diambil sebagai responden, dan subjek penelitiannya adalah orang yang menduduki jabatan sebagai pemimpin, dalam hal ini Kepala Bagian dan Kepala Sub Bagian di Biro Kepegawaian Sekretariat Daerah Provinsi Jawa Barat yang berjumlah 17 orang.

Teknik analisis data yang digunakan pada penelitian ini adalah teknik analisis data regresi sederhana. Analisis data ini digunakan untuk menjawab rumusan masalah yaitu "Adakah Pengaruh Sistem Informasi Manajemen Kepegawaian terhadap 
Pengambilan Keputusan Pimpinan dalam Pengembangan Karier Pegawai Biro Kepegawaian Sekretariat Daerah Provinsi Jawa Barat. Analisis regresi adalah menganalisa data dengan cara mendeskripsikan atau menggambarkan data-data dari variabel yang diteliti, apakah sesuatu variabel disebabkan atau dipengaruhi ataukah tidak oleh variabel lainnya

\section{HASIL DAN PEMBAHASAN}

Hasil uji hipotesis terhadap proposisi hipotetik yang diajukan akan diuraikan pada bagian ini. Seluruh pengolahan data untuk pengujian hipotesis menggunakan bantuan aplikasi SPSS versi 23. Pengujian koefisien regresi dapat dilakukan dengan memperhatikan langkah-langkah pengujian hipotesis berikut.

a. Menentukan rumusan hipotesis $\mathrm{H}_{0}$ dan $\mathrm{H}_{1}$

Hipotesis penelitian statistik $\left(\mathrm{H}_{0}\right.$ dan $\left.\mathrm{H}_{1}\right)$ yang sesuai dengan hipotesis penelitian yang diajukan, yaitu:

$\mathrm{H}_{0}: \rho \neq 0$, artinya tidak terdapat pengaruh antara Sistem Informasi Manajemen Kepegawaian terhadap Pengambilan Keputusan Pimpinan dalam Pengembangan Karier Pegawai Biro Kepegawaian Sekretariat Daerah Provinsi Jawa Barat.

$\mathrm{H}_{1}: \rho>0$, artinya terdapat pengaruh antara Sistem Informasi Manajemen Kepegawaian terhadap Pengambilan Keputusan Pimpinan dalam Pengembangan Karier Pegawai Biro Kepegawaian Sekretariat Daerah Provinsi Jawa Barat.

b. Penentuan taraf kemaknaan $\alpha$ (level of significance $\alpha$ ), yaitu $\alpha=5 \%$.

Hasil pengolahan data menggunakan program SPSS dipaparkan sebagai berikut:

Tabel 1. Hasil Pengolahan Uji t

Coefficients $^{a}$

\begin{tabular}{|c|c|c|c|c|c|c|}
\hline \multirow{2}{*}{\multicolumn{2}{|c|}{ Model }} & \multicolumn{2}{|c|}{ Unstandardized Coefficients } & \multirow{2}{*}{$\begin{array}{c}\begin{array}{c}\text { Standardized } \\
\text { Coefficients }\end{array} \\
\text { Beta }\end{array}$} & \multirow[b]{2}{*}{$t$} & \multirow[b]{2}{*}{ Sig. } \\
\hline & & $B$ & Std. Error & & & \\
\hline \multirow[t]{2}{*}{1} & (Constant) & 1.274 & .734 & & 1.737 & .101 \\
\hline & SIMAK & .694 & .175 & .694 & 3.969 & .001 \\
\hline
\end{tabular}

a. Dependent Variable: Keputusan 
Hasil pengolahan data pada tabel 1 menunjukkan bahwa nilai signifikansinya sebesar 0,001 yang lebih kecil dibandingkan $\alpha$ (level of significance $\alpha$ ), yaitu $\alpha=$ $5 \%$ atau 0,05 . Sehingga dapat disimpulkan bahwa Ha diterima dan Ho ditolak yang berarti variabel SIMAK (Sistem Informasi Manajemen Kepegawaian) memiliki pengaruh yang signifikan terhadap Pengambilan Keputusan Pimpinan dalam Pengembangan Karier Pegawai.

Sedangkan untuk pengujian hipotesis menggunakan uji $\mathrm{F}$ hasilnya sebagai berikut:

Tabel 2. Hasil Analisis Uji F

ANOVA ${ }^{\mathrm{b}}$

\begin{tabular}{|rl|r|r|r|r|r|}
\hline Model & & \multicolumn{1}{|c|}{$\begin{array}{c}\text { Sum of } \\
\text { Squares }\end{array}$} & df & Mean Square & F & Sig. \\
\hline 1 & Regression & 3.139 & 1 & 3.139 & 15.756 & $.001^{\text {a }}$ \\
& Residual & 3.387 & 17 & .199 & & \\
& Total & 6.526 & 18 & & & \\
\end{tabular}

a. Predictors: (Constant) SIMAK

b. Dependent Variable: Keputusan

Berdasarkan perhitungan di tabel 2 diperoleh $F_{\text {hitung }}$ sebesar 15.756, sedangkan $F_{\text {tabel }}$ sebesar 4.540, artinya $\mathrm{F}_{\text {hitung }}>\mathrm{F}_{\text {tabel }}$ yaitu $15.756>4.540$, maka $\mathrm{H}_{\mathrm{o}}$ yang menyatakan tidak ada pengaruhnya ditolak dan tentu saja $\mathrm{H}_{\mathrm{a}}$ yang menyatakan ada pengaruh diterima.

Berdasarkan hasil uji terhadap 17 orang Pimpinan di Biro Kepegawaian Sekretariat Daerah Provinsi Jawa Barat diperoleh keterangan objektif bahwa terdapat pengaruh antara Sistem Informasi Manajemen Kepegawaian terhadap Pengambilan Keputusan Pimpinan dalam Pengembangan Karier Pegawai Biro Kepegawaian Sekretariat Daerah Provinsi Jawa Barat.

Berdasarkan hasil perhitungan yang telah dijabarkan di atas, diperoleh nilai koefisien determinasi variabel sistem informasi manajemen kepegawaian (X) terhadap pengambilan keputusan pimpinan dalam pengembangan karir pegawai (Y) adalah $0,694^{2} \times 100 \%=48,1 \%$. Artinya, Pengambilan Keputusan Pimpinan dalam Pengembangan Karier Pegawai dipengaruhi oleh Sistem Informasi Manajemen Kepegawaian sebesar 48,1\%. Sisanya sebesar 51,9\% dipengaruhi oleh faktor lain yang tidak dikaji dalam penelitian ini. 


\section{Pembahasan}

Peneliti melakukan uji statistik, setelah diketahui bahwa data penelitian berdistribusi normal, linier dan homogen, kemudian peneliti menggunakan statistik parametrik dalam menguji hipotesis penelitian.

Pengujian hipotesis yang peneliti lakukan, bertujuan untuk suatu kesimpulan bahwa Sistem Informasi Manajemen Kepegawaian memberikan pengaruh terhadap Pengambilan Keputusan Pimpinan dalam Pengembangan Karier Pegawai, artinya tinggi atau rendahnya Pengambilan Keputusan Pimpinan dalam Pengembangan Karier Pegawai dipengaruhi oleh Sistem Informasi Manajemen Kepegawaian.

Berdasarkan hasil perhitungan regresi sederhana diperoleh persamaan regresi linier Pengambilan Keputusan Pimpinan dalam Pengembangan Karier Pegawai atas Sistem Informasi Manajemen Kepegawaian yaitu $\hat{Y}=1.274+0.694 X$. Hal ini berarti Pengambilan Keputusan Pimpinan dalam Pengembangan Karier Pegawai Pegawai bernilai 1.274 jika Sistem Informasi Manajemen Kepegawaian tidak berjalan dengan baik, tetapi jika Sistem Informasi Manajemen Kepegawaian berjalan dengan baik maka pelaksanaan Pengambilan Keputusan Pimpinan dalam Pengembangan Karier Pegawai Pegawai akan meningkat sebesar 0.694. Hal ini berarti setiap penambahan sebesar 1 maka Sistem Informasi Manajemen Kepegawaian akan meningkatkan Pengambilan Keputusan Pimpinan dalam Pengembangan Karier Pegawai di lingkungan Biro Kepegawaian Seketariat Daerah Provinsi Jawa Barat sebesar 0,694.

\section{SIMPULAN DAN SARAN}

\section{Simpulan}

Pelaksanaan pengembangan karier di lingkungan Biro Kepegawaian Sekretariat Daerah Provinsi Jawa Barat belum dapat dilaksanakan dengan baik dan terstruktur. Disini dapat dilihat bahwa pimpinan di lingkungan Biro Kepegawaian Sekretariat Daerah Provinsi Jawa Barat belum dapat melaksanakan fungsi sistem informasi manajemen kepegawaian dalam menunjang pemimpin untuk dapat mengambil keputusan bagi pengembangan karier pegawainya. Sehingga dapat dihasilkan pegawai yang benar-benar memiliki kinerja yang baik sesuai dengan fungsi dan 
jabatannya masing-masing yang ditunjang berdasarkan informasi yang diperoleh pimpinan dari sistem informasi manajemen kepegawaian.

Berdasarkan perhitungan pengujian hipotesis diperoleh $F_{\text {hitung }}$ sebesar 15.756, sedangkan $F_{\text {tabel }}$ sebesar 4.540 , artinya $F_{\text {hitung }}>F_{\text {tabel }}$ yaitu $15.756>4.540$, maka $\mathrm{H}_{\mathrm{o}}$ yang menyatakan "Sistem Informasi Manajemen Kepegawaian tidak berpengaruh positif dan signifikan terhadap Pengambilan Keputusan Pimpinan dalam Pengembangan Karier Pegawai" ditolak dan tentu saja $\mathrm{H}_{a}$ yang menyatakan "Sistem Informasi Manajemen Kepegawaian berpengaruh positif dan signifikan terhadap Pengambilan Keputusan Pimpinan dalam Pengembangan Karier Pegawai” diterima. Sehingga dapat disimpulkan bahwa hipotesis" Sistem Informasi Manajemen Kepegawaian berpengaruh positif dan signifikan terhadap Pengambilan Keputusan Pimpinan dalam Pengembangan Karier Pegawai di lingkungan Biro Kepegawaian Seketariat Daerah Provinsi Jawa Barat" diterima.

\section{Saran}

Sistem Informasi Manajemen Kepegawaian akan meningkatkan Pengambilan Keputusan Pimpinan dalam Pengembangan Karier Pegawai di lingkungan Biro Kepegawaian Sekretariat Daerah Provinsi Jawa Barat. korelasi antara Sistem Informasi Manajemen Kepegawaian dan Pengambilan Keputusan Pimpinan dalam Pengembangan Karir Pegawai dapat digeneralisasikan atau berlaku untuk seluruh responden.

\section{DAFTAR PUSTAKA}

Arikunto, S. (2010). Prosedur Penelitian Suatu Pendekatan Praktek (Edisi Revisi 2010). Jakarta: Rineka Cipta.

Erpurini, W. (2019). Pengaruh Sistem Informasi Manajemen Kepegawaian (Simpeg) Dan Lingkungan Kerja Terhadap Kinerja Karyawan Pada Instalasi Narkotika, Psikotropika Dan Zat Adiktif (Napza) Rumah Sakit Jiwa Provinsi Jawa Barat. Geo Ekonomi, 10(1).

Hasibuan, M. (2014). Manajemen Sumber Daya Manusia, edisi revisi, cetakan kedelapanbelas. Bumi Aksara.

Hayati, Y. (2004). Perilaku Organisasi. Bandung: Alfabeta.

Ibnu, S. (2000). Pengambilan Keputusan dan Sistem Informasi. Jakarta: Bumi Aksara. 
Lasmaya, M. (2016). Pengaruh Sistem Informasi SDM, Kompetensi dan Disiplin Kerja Terhadap Kinerja Karyawan. Jurnal Ekonomi, Bisnis \& Entrepreneurship, 4(2).

Lipursari, A. (2013). Peran sistem informasi manajemen (SIM) dalam pengambilan keputusan. Jurnal Stie Semarang, 5(1).

Mangkunegara, A. P. (2013). Manajemen Sumber Daya Manusia Perusahaan. Bandung: Rosdakarya.

Yapary, F. V. (2013). Pengaruh Sistem Informasi Manajemen SDM Terhadap Pengambilan Keputusan Pengembangan Karir Pada PT. Bank Tabungan Pensiun Nasional, Tbk. Jurnal Ilmu Administrasi, 9(3). 